\title{
KRITIK SASTRA PUITIKA KULTURAL STEPHEN GREENBLATT: METODE DAN PRAKTIK ANALISIS
}

\author{
Moh. Fathoni \\ Sastra Inggris Fakultas Sastra Universitas Ahmad Dahlan Yogyakarta \\ Email: fath_email@yahoo.co.id
}

\begin{abstract}
Abstrak
Sebagai eksponen new historisisme, Greenblatt menggagas puitika kultural dalam kritik sastra. Pemikiran Greenblatt yang luas dan ekletik dari berbagai ranah disiplin dan mengadopsi teori pemikir lain memperkuat praktik dalam menganalisis teks sastra. Sementara tulisan-tulisan Greenblatt yang berupa analisis teks sastra tidak secara baku merumuskan teori dan metode praksisnya. Hal ini pada sisi lain memungkinkan bagi siapapun memformulasikan teori dan metode untuk analisis sesuai dengan kritik sastra yang dilakukannya. Tulisan ini berupaya merumuskan kritik sastra puitika kultural Stephen Greenblatt dengan berusaha menelusuri dan memahami praktik analisisnya melalui karya- karyanya. Perumusan gagasan Greenblatt tersebut dilakukan dengan mengidentifikasi beberapa buku yang menjadi karya utamanya dalam praktik analisis teks sastra, yang antara lain Renaissance Self-Fashioning: From More to Shakespeare (1980), Shakespearean Negotiations: The Circulation of Social Energy in Renaissance England (1988), dan Marvelous Possessions: The Wonder of the New World (1991).
\end{abstract}

Kata Kunci: new historisisme, greenblatt, puitika

\section{Abstract}

As an exponent of new historicism, Greenblatt initiated cultural poetic in literary criticism. The broad and eclectic of Greenblatt's thought in various disciplines and also what he had adopted from other thinkers" theory strengthen in practising literary texts analysis, while Greenblatt's writings about literary texts analysis were not formulated in the form of theories and praxis methods. In the other hand, it makes possible for anyone to formulate theories and methods for analysis according to literary criticism does. This paper describes a poetic culture literary critic of Stephen Greenblatt by trying to explore and understand the world through the analysis of his works. The formulation of Greenblatt's thought was proccesed by identifying some of his major books in the practice of literary text analysis, such as Renaissance Self - Fashioning: From More to Shakespeare (1980), Shakespearean Negotiations: The Circulation of Social Energy in Renaissance England (1988), and Marvelous possessions: The Wonder of the New World (1991).

Keywords:new historicism, Greenblatt, poetic

\section{Pendahuluan}

Stephen Greenblatt merupakan salah satu eksponen dari gerakan new historicism, sebuah gerakan yang menolak aliran new criticism, formalisme, dan sekaligus historisisme lama di Amerika. Sebagai pelopor gerakan, Greenblatt baru secara terang memperkenalkan new historisisme pada 1982. New historisisme Greenblatt mencakup beragam pandangan dengan mengadopsi berbagai pandangan pemikir lain, beberapa diantaranya seperti Foucault, Jameson, Geertz, Williams, Lyotard, Derrida, dan lainnya. Keluasan dan keragaman tersebut membuat pemikirannya sulit dirumuskan seperti yang tampak dalam perbedaan pendapat dan tanggapan Alan Liu (1989: 721), John
Brannigan atau Claire Colebrook (1998) dan A. E. B. Coldiron (2001: 97). Atau, kemudian pengembangan yang cukup beragam, seperti Chung-Hsiung Lai, Jane Marcus dan Judith Lowder Newton dalam feminism (Marcus, 1989: 132); Donald Pease dalam postcolonial (1991: 108); Jan R. Veenstra melalui hermeneutika (1995: 174-198), dan lainnya.

Tulisan-tulisan Greenblatt yang tersebar di berbagai jurnal dan di dalam buku lebih mengedepankan praktik analisis daripada teori. Dari buku-buku yang secara ketat menguraikan praktik analisis karya sastra kemudian oleh para pengikut new historisisme dijadikan sebagai contoh model kritik sastranya. Dalam hal ini Greenblatt menyatakan bahwa ia memang ingin 
menunjukkan dan mendahulukan praktik dari pada konsep teoretiknya. Bahkan diakuinya bahwa new historisisme tidak pernah dirumuskan sebagai suatu proposisi teoretik yang sudah selesai (Greenbalt, 2000: 1).

Di Indonesia, new historisisme sudah digunakan oleh para akademisi. Beberapa di antaranya oleh Taum, Asep Samboja, Nurhadi, Melani Budianta, dan Bambang Purwanto dengan memilih penekanan tertentu dari gagasan besar new historisisme, tetapi kurang memberikan perhatian pada pemikiran khas Greenblatt: puitika kultural. Dengan beberapa alasan tersebut, maka dalam tulisan ini akan memeriksa kembali buku-buku Stephen Greenblatt yang dijadikan acuan bagi praktik new historisisme beserta dasar pemikirannya.

\section{Stephen Greenblatt: Kehidupan dan Latar Pemikirannya}

Latar kehidupan dan karier Greenblatt dapat ditemukan pada teks wawancara dengan Jeffrey J. William yang dimuat dalam "Critical Self-Fashioning: An Interview with Stephen J. Greenblatt," Minnesota Review, 71-72 (2009), dan dalam bab tentang Bibliografi Stephen Greenblatt edisi Norton Anthology of Theory and Criticism (2010: 2146-50).

Greenblatt lahir di Boston (1928). Ayahnya seorang pengacara, dan Kakeknya adalah imigran dari Lithuania. Ia mendapatkan B.A. dari Yale University pada tahun 1964 dan Ph.D tahun 1969 dari universitas yang sama. Setelah itu, selama dua tahun ia ke Cambridge University di London untuk mengikuti kuliah Raymond Williams. Selain itu, ia mengembangkan minatnya pada sastra masa Renaissans. Pada tahun 19691997 ia mengajar di University of California. Kemudian ia pindah dan mengajar di Harvard University, kampus yang kemudian memberinya gelar profesor humaniora.

Semasa ia kuliah di Yale University mode kritik di Amerika didominasi oleh New Kritisisme, demikian pula di kampusnya khususnya dipengaruhi oleh Cleanth Brooks dan William K. Wimsatt Jr. Beberapa mahasiswa yang mendapatkan keuntungan dari kritik formalisme di Yale University, antara lain Stanley Fish dan Harold Bloom. Fish dengan gagasan affective fallacy dimana makna bukan pada puisi tetapi pada pembaca, sedangkan Bloom dengan intentional fallacy yang fokus pada pengarang dan perjuangan psikisnya melawan para pendahulunya. Sementara Greenblatt memfokuskan perhatiannya pada keadaan historis dan biografis yang melingkupi karya sastra.

Ketika di Cambridge, khususnya dari Raymond Williams, Greenblatt mempelajari aspek-aspek sosial dari sastra. Tetapi, Greenblatt tidak kemudian menjadi Marxis sebagaimana Williams. Ia justru lebih banyak mengadopsi gagasan Michel Foucault dan antropologi kultural Clifford Geertz.

Berdasarkan dari Discipline and Punishnya Foucault, Greenblatt memeriksa cara-cara masyarakat modern menggunakan kontrol melalui disiplin, tekanan dengan yang subtil, daripada kekuasaan secara terang- terangan secara fisik. Bermula dari Discipline and Punish kemudian karya-karya Foucault lainnya, ia dan juga para pemikir new historisisme lainnya mengembangkan gagasan tersebut.

Gagasan Foucautldian yang mencolok, misalnya, new historisisme mengikuti pandangan bahwa terdapat subversi dan pengurungan (containment) di dalam sistem masyarakat modern. Sebagaimana yang tampak pada praktiknya, subversi akan meruntuhkan disiplin atau ketertiban, tetapi perlawanan tersebut akan memicu pembentukan kembali sistem yang teratur. Protes terhadap ketidakadilan pemerintah, misalnya. Tindakan protes tersebut menegaskan bahwa di bawah pemerintah masyarakat memiliki kebebasan, tetapi juga pada sisi lain, protes justru memperkuat kontrol pemerintah yang lebih menyeluruh terhadap warga negaranya.

Pada paruh pertama abad ke-20 pemikiran kritis Amerika didominasi oleh pandangan yang memberatkan pada kritik historis dan teori sastra. Beragam gagasan kritis didikotomi secara ekstrem antara otonomi tekstual pada sastra di satu sisi, dan di sisi lain tekstual pada sisi historis. 
Kritisisme historis cenderung menganggap bahwa suatu teks sebagai sesuatu transparan, yang segera menyediakan suatu pemahaman terhadap realitas. Referensi tekstual terlihat jelas sebagaimana dalam pandangan realisme. Pada hal lain, upaya untuk mendapatkan informasi makna dipandang sebagai sebuah proses yang tidak terhalangi oleh apapun dan bersih oleh tugas interpretasi dari pembaca (dalam pengertian subjektivitas).

Padatahun1980-andiskusisastradiAmerika didominasi oleh perdebatan- perdebatan teori yang berlebihan, terutama perihal status bahasa, seperti para akademisi yang mempertanyakan nilai referensial dan kewenangannya untuk membangun atau merusak makna. Penekanan perhatian dalam pembicaraan sastra tersebut berakar dari pengaruh paradigma positivistik sebagaimana yang dilakukan oleh new kritisisme yang mengisolasi teks dari lingkungan sekitarnya.

Kritik sastra seperti yang dipraktikkan new kritisisme, dan formalisme, yang memperlakukan dan menghormati teks sebagai sesuatu entitas yang otonom. Kritik tersebut berusaha objektif dengan tujuan mengartikulasikan makna dan tulisan dari suatu teks dalam pengertian sistem-bahasa intrinsik. Prinsip hati-hati dalam menganalisis suatu teks membuat mereka menghindari semua keterkaitan teks dengan lingkungan di luar, kondisi konteks dimana teks berada diabaikan. Dampaknya, dunia pengarang, pembaca, dan keadaan sosial menjadi sesuatu yang terlarang, seperti close reading.

Sebagaimana disebutkan di atas, dalam perjalanan pemikirannya di Yale University Greenblatt memfokuskan perhatiannya pada keadaan historis dan biografis yang melingkupi karya sastra. Ia memandang bahwa seni merupakan produk dari keadaan historis yang khas dan konvensi-konvensi tertentu. Konvensi tersebut diantaranya adalah politik, sejarah, budaya, atau diskursus yang melingkupinya, yang semuanya berjejalin satu sama lain, sebagaimana 'sebuah keseluruhan, jaringan berkabut dari pembatasan dan pemberian-nama, mimpi dan praktik-praktik yang menghubungkan kita pada dunia'.
Selain itu, tampak jelas pula bahwa Greenblatt mengikuti pandangan sejarah postrukturalismeyang memandang bahwasejarah merupakan hasil konstruksi, bersifat tekstual, dan memiliki kontradiksi di dalam dirinya (selfcontradictory). Dengan dasar demikian, Greenblatt mengkritik pemutusan teks dari konteks sosiohistorisnya. Dari beberapa buku utamanya, Greenblatt mengadopsi pemikiran antropologi, terutama Clifford Geertz. Darinya Greenblatt mengadopsi pandangan artefak kultural, dimana budaya sebagai suatu teks beserta praktik dan jalinan kultural dalam konteks sosiohistorisnya. Dalam hal ini, yang paling mencolok adalah analisisnya dalam merepresentasikan dinamika kekuasaan dan gender pada masa renaissans.

Dalam konteks demikian, Brannigan menyebut bahwa objek kajian Greenblatt adalah bukan teks atau konteksnya, bukan sastra atau sejarahnya, tetapi lebih pada sastra 'dalam' sejarah (1998: 3-6). Demikian dengan Montrose menyebut bahwa 'tekstualitas sejarah dan historisitas teks' (Brannigan, 1998: 84). Maka, tekstualitas sejarah berarti mengasumsikan adanya perbedaan historis, sedangkan historisitas teks mengacu pada pembacaan suatu teks.

Dua pemikir utama yang paling mempengaruhi Greenblatt adalah Michel Foucault dan Clifford Geertz. Melalui Foucault, Greenblatt menyerap gagasan tentang diskursus dan implikasinya dalam kritik atas kekuasaan dan sejarah. Dengan demikian, dari Foucault kemudian Greenblattmemasukianalisis diskursus melalui pengarang dan sejarah yang melekat padanya; dari Geertz, Greenblatt mendasarkan praktik analisisnya dalam hal tekstulitas budaya dan realitas simbolik. Sedangkan dari (post) marxis seperti, utamanya Williams dan Jameson, ia mengembangkan strategi dialektis dan metaforik dalam praktik kritisnya.

\section{Pemikiran Greenblatt dalam Karya- Karyanya \\ Karya Greenblatt pertama sebenarnya bukan Renaissans Self-Fashioning: From More to Shakespeare (1980), tapi Three Modern Satirist: Wangh, Orwell, and Huxley (1965). Meski buku}


pertama yang merupakan tesisnya tersebut mengarah pada kajian pengarang dan konteks historis, tapi belum mengarah pada konsepsi $a$ poetic of culture dan new historisisme. Demikian juga pada buku keduanya, Sir Walter Ralegh: The Renaissance Man andHis Roles (1973). Buku tersebut merupakan pengembangan dari disertasinya, dimana perhatian Greenblatt bergeser dari konteks sejarah masa modern ke renaissans. Dalam buku keduanya ini ia menemukan dan mempertanyakan terus- menerus persoalan kepengarangan yang dibentuk oleh persona dalam historisitas yang melingkupinya.

Pandangan tersebut terus dikembangkan sampai terbit buku ketiganya, Renaissans SelfFashioning: From More to Shakespeare (1980) yang merupakan semacam deklarasi atas pemikirannya, sekaligus mengukuhkannya sebagai kritikus sastra yang disegani. Buku ketiga Greenblatt tersebut melanjutkan apa yang sudah diperiksanya pada buku-buku sebelumnya dengan lebih rinci dan kuat.

Namun, Greenblatt tidak berhenti pada pengarang dan relasinya dengan konteks historisnya, ia juga memperlakukan teks, pengarang, dan konteks historisnya dalam suatu jaringan pemaknaan. Pemaknaan suatu teks tidak terhindarkan dari perkara diskursus yang kemudian beroperasikan kekuasaan dalam mendominasi, mengontrol, dan membentuk pengarang, teks, dan konteksnya. Tetapi, relasi tersebut tidak stabil atau bersifat deterministik. Dalam hal ini kritik sastra berupaya membaca dan memberikan makna dengan bernegosiasi dengan ketiganya secara dialektik dan tidak terpisahkan.

Hasil pengkajian tersebut di dalam Renaissance Self-Fashioning, oleh Greenblatt disebut dengan 'a poetics of culture'(1980: 5) yakni dalam rangka menemukan konsep utama self-fashioning. Pengkajian tersebut dilakukan terhadap karyakarya More, Wyatt, Tyndale, Spencer, Marlowe, dan Shakespeare. Greenblatt ingin membuktikan bahwa pada abad ke-16 tampak meningkatnya kesadaran diri mengenai pembentukan (fashioning) identitas manusia sebagai sesuatu yang dapat dimanipulasi” (1980: 2) sehingga dibuktikan bahwa "narasi dan identitas sosial dibentuk di dalam budaya" (1980: 6).

Selang dua tahun kemudian, ia menerbitkan artikel "The Power of the Forms in the English Renaissance" dalam jurnal Genre (1982) yang secara terang-terangan mendeklarasikan 'new historisisme'. Tahun 1985 bersama Raymond Williams, Alan Sinfield, Jonathan Dollimore, dan pemikir materialisme kultural lainnya menerbitkan Political Shakespeare. Buku tersebut menunjukkan kecenderungan dan kedekatan pemikiran Greenblatt pada marxisme, selain diakuinya Greenblatt dalam kajian renaissans dan Shakespeare.

Tulisan-tulisan Greenblatt pada tahun 1980an diterbikan oleh Genre, dan Representation yang kemudian dianggap sebagai media yang menjadi corong gerakan new historisisme. Selain itu, artikel-artikel Greenblatt juga dimuat ulang, diterjemahkan, dan dijadikan antologi dalam beragam tema. Hal ini memungkinkan ketersebaran gagasan Greenblatt dalam dunia pemikiran dan ia dijadikan sebagai pemuka dalam gerakan new historisisme.

Buku utama berikutnya ialah Shakespearean Negotiations: The Circulation of Social Energy in Renaissance England (1988). Dalam buku tersebut Greenblatt mengembangkan gagasan self-fashioning dengan penggunaan pola-pola negosiasi dan pertukaran dalam relasi sosiohistoris. Buku ini disebut juga menunjukkan bahwa Greenblatt tidak sekedar mengadopsi konsep kekuasaan Foucault dan kesadaran marxisme. Greenblatt menggunakan metafor ekonomi untuk menjembatani antara teks, pengarang, dan konteks. Keterhubungan tersebut diwujudkan dalam pola negosiasi dan pertukaran barang- barang simbolik dan energi sosial dapat beroperasi.

Bagi Greenblatt bahwa pengarang, teks, pembaca, dan masyarakat bukan fenomena yang terpisah dan tidak mungkin dipisahkan, tetapi, semua itu berjalinan, menyusun dan mengisi dalam suatu rangkaian diskursus. Dengan mengungkapkan unsur politis dari teks dan mempertegas eratnya keterikatan dengan lingkungan sosiohistoris, Greenblatt tidak 
hanya memeriksa kesadaran subjek dan makna teks pada periode historis tertentu, tetapi juga membuat pembaca menyadari bahwa masyarakat dan sejarah merupakan kekuatan utama dalam produksi makna teks.

Tahun 1990 Greenblatt mengumpulkan beberapa artikelnya dan menerbitkannya dalam Learning to Curse: Essays in Early Modern Culture. Di antaranya artikel yang dimuat adalah "Toward A Poetics of Culture" di dalamnya Greenblatt menyatakan bahwa new historisisme bukan suatu doktrin yang baku dan definitif. Ia juga berbeda pandangan dengan estetika marxisme, dan Jameson khususnya dalam The Political Unconscious, yang menurut Greenblatt, Jameson membuka jarak antara yang privat dan publik, yang sosial dan psikologis, yang politik dan puitik. Bagi Greenblatt ia mengakui bahwa pandangan estetika marxisme mengarah dari diferensiasi ke totalisasi. Hal yang tolak belakang dengan post-strukturalisme, Lyotard dan Derrida khususnya. Greenblatt memposisikan dirinya di antara keduanya, tidak berhenti pada salah satunya dan terus bergerak bolakbalik di antara keduanya. Dengan demikian, ia menyebutnya dengan pengertian sirkulasi dan negosiasi. Hasilnya, ia menyatakan bahwa karya seni merupakan produk negosiasi antara pengarang atau kelas pengarang yang kompleks berjalinan, yang telah disajikan secara komunal dalam suatu konvensi, oleh suatu institusi dan masyarakat yang melingkupinya dengan berbagai praktik dan fenomena kultural, yang dikonstruksi dan dimanipulasi. Demikian pada akhirnya tidak ada karya seni yang benar-benar asli, mandiri, otonom atau otentik. Maka, suatu karya ditentukan oleh keberhasilan pengarang dalam bernegosiasi untuk memunculkan suatu makna.

Sedangkan di dalam buku utama berikutnya, Marvellous Possessions: The Wonder of the New World (1992), Greenblatt mengkaji teks-teks dengan menguraikan strategi-strategi kekuasaan yang diproduksi masa penaklukan (imperial). Ia mencoba menunjukkan suatu penguraian dan analisis yang cermat dengan menekankan bahwa suatu teks diinformasikan oleh dialektika kultural yang sama sebagai masyarakat luar. Menurutnya, sebuah teks juga merefleksikan sandaran dialektika tersebut, atau menempatkannya pada posisi yang berbeda yakni suatu konteks sosiohistoris mengkondisikan representasi tekstual dan demikian juga suatu teks yang menginformasikan dan kadangkala sejajar dengan kondisi proses historis.

Dengan demikian, representasi merupakah bagian dari kapital mimetis yang beredar di dalam suatu masyarakat tertentu dan memungkinkan proses asimilasi. Dalam hal ini Greenblatt menekankan perhatiannya pada perbedaan antara petities histories (sejarah kecil), sifat-dasar fragmented (terpisah-pisah dan tidak lengkap) yang masih memberikan kesaksian akan shock pertemuan dengan alteritas, dan sejarah besar pentotalisasian dimana semua yang berbeda disatukan, diasimilasikan, dan direduksi pada kesamaan (sameness).

Greenblatt lebih memihak sejarah kecil (petities histories) yang menandakan panggung pertama dari proses asimilasi tersebut, sejak pengarang sangat berminat pada ketakjuban dan keheranan pada penglihatan dunia baru dan orang-orang yang tidak dikenalinya. Proses dialektika tersebut oleh Greenblatt dioperasikan oleh teks sebagaimana narasi-narasi secara kuat menentukan interpretasi, seperti yang ia tunjukkan dalam Travels-nya Mandeville dan surat-suratnya Columbus. Sekali lagi, dalam buku ini Greenblatt tetap menggunakan simbolik interpretatif Geertz.

Pada 2000 Greenblatt kembali mengumpulkan dan menerbitkan artikelartikelnya dalam Practicing New Historicism bersama dengan Catherine Gallagher. Diantara artikel yang terang memuat konsepsi pemikiran Greenblatt adalah artikel "The Touch of the Real" yang sebelumnya dimuat oleh Jurnal Representation (1997:14-29). Dalam artikel tersebut Greenblatt kembali menyatakan bahwa antara tulisan sastra dan antropologi adalah sama, yakni sebuah teks yang dikonstruksi oleh imajinasi dan cerita (narasi) meski dalam penguraiannya Greenblatt tampak seperti retorik tapi menurutnya ia menggunakan cara anekdot dan parodi. Ia juga 
menunjukkan kesamaan tersebut antara teks Geertz (Interpretation of Culture) dengan Gustav Faubert (Madame Bovary) dan Shakespeare. Dalam hal ini Greenblatt mengikuti diktum terkenal Derrida: There is nothing outside the text.

$$
\text { Berikutnya Greenblatt kembali }
$$
menerbitkan artikel-artikelnya dalam buku Hamlet in Purgatory (2002) dan Will in the World (2004). Dalam buku pertama Greenblatt sampai pada kesimpulan bahwa nama "Hamnet" tokoh Shakespeare berkaitan erat dengan nama seorang anak laki-laki" Shakespeare yang meninggal pada usia 11 tahun, "Hamnet". Kesimpulan tersebut jelas didasarkan pada pembacaan biografis pengarang. Menurut Greenblatt, setelah kematian putranya Shakespeare tampak dingin dan seperti tidak bereaksi apa-apa di dalam karyanya. Dalam hal ini ada yang beranggapan bahwa Hamnet adalah anak haram Shakespeare dari istri pertamanya. Prasangka ini disebabkan setelah kematian itu Shakespeare menulis, seperti "Much Ado About Nothing", "Merry Wives of Windsor" atau "As You Like It', yang justru hendak menunjukkan kegembiraan dan mengumbar gelak-tawa, sedang adegan pernikahan yang menyenangkan dikaitkan dengan pernikahan Shakespeare dengan istri keduanya.

Namun, hal tersebut berbeda setelah 5 tahun (1601) dari kematian putranya, Shakespeare menulis Hamlet. Di sini Greenblatt menghubungkan teks (karakter) dengan kehidupan pengarang, terutama penguraian psikologis secara mendetail. Jika dibandingkan misalnya dengan tragedy "Richard III" yang masih kasar, "Hamlet" yang sama kejam, jahat, dan sejenisnya tapi dengan bangunan cerita yang kuat.

Kemudian, Greenblatt mengarahkan uraiannya pada diskursus. Menurutnya, Hamlet adalah duri yang masuk di dalam kerongkongan peradaban Barat, sementara pembaca mencoba menelan dan meludahkannya terus-menerus. Kasus Hamlet ini sebenarnya terjadi dimanamana, ia juga berlaku pada Freud, dan Marx. Sebagaimana hal yang sering-sangat membayang di dalam kehidupan, dan tidak terjadi tidak hanya 'di sini'. Ia terjadi dengan luar biasa mendorong dan melemparkannya keluar.

Menurut Greenblatt, karya-karya Shakespeare memuat pandangan skeptis terhadap sistem monarki yang karismatik pada masa hidup. Misalnya dalam "Henry V", Shakespeare menggambarkan seorang raja pejuang yang karismatik. Pada satu sisi diungkapkan suatu perayaan akan heroisme yang meriah. Di sisi lain raja tersebut digambarkan memerintahkan pembunuhan massal orang-orang yang dipenjara, melanggar aturan-aturan perang, mengancam akan memperkosa (cabul), bertindak dengan cara-cara yang luar biasa. Sehingga, bagi Greenblatt, Shakespeare memperhatikan adanya otoritas yang kharismatik yang jalin-menjalin dengan tindakan kejahatan. Analisis Greenblatt tersebut menyarankan penggunaan metode dialektik, yang didahului dengan pencarian oposisi berlawanan, dalam konteks kekuasaan Foucauldian.

Sementara dari beberapa artikel lainnya dalam buku tersebut, salah satu yang terpenting adalah "The Touch of the Real'. Dalam tulisan tersebut Greenblatt menyatakan tetap menggunakan 'thick descriptionI' dalam membaca teks-teks Shakespeare. Ia juga mengarahkan pembacaannya dengan mencoba membawa Shakespeare kembali ke dalam dunia dimana ia hidup dan di dalam dunia pembaca yang kini.

Belakangan, dewasa ini Greenblatt terus melanjutkan konsep narasi historis. Pada 2010 ia menulis The Cultural Mobility: A Manifesto (2010:250-253) bersama dengan Pannewick, Zupanov, dan pemikir lainnya, Greenblatt membuat semacam manifesto dalam rangka reorientasi asumsi-asumsi tradisonal mengenai identitas kultural dalam teks-teks travel writing. Greenblatt memeriksa kembali gagasan keseluruhan (wholeness), pembangunan teleologis, kemajuan evolusioner, dan kemurnian etnis yang dikatakan telah dibongkar seiring dengan teori-teori hibriditas, jaringan (network), dan arus persilangan informasi, barang, orang, uang yang kompleks, dan pandangan lain yang ingin mempertahankan suatu identitas nasionalisme, agama, dan etnis di hadapan politik global atau realitas kekinian yang terus-menerus bergerak. 
Persoalan-persoalan tersebut ditempatkan pada diskursus kultural tertentu beserta perubahannya, kemudian dianalisis sesuai dengan kompetensi penulis masing-masing. Berangkat dari karyakaryaShakespeare khususnya Cardenio, Greenblatt kemudian menempatkan Shakespeare dalam bangunan kultur renaissans dan ruang diskursus mobilitas kultural. Tampaknya Greenblatt masih konsisten menggunakan strategi dialektis dalam analisisnya.

Dalam buku yang disebut manifesto ini Greenblatt menulis bagian pengantar dan penutupnya. Pada bagian penutup Greenblatt menulis 'semacam' manifesto. Dalam hal ini ia mencoba memperluas kajiannya dengan beragam isu dari kolonial, postkolonial, feminisme, psikoanalisis, sampai pada kajian budaya (cultural studies) seperti identitas kultural dan etnisitas, tetapi tetap dalam kerangka pendekatan new historisisme. Mobilitas, yang menjadi masalah utama dalam buku ini, diungkapkan dalam merespon kemapanan budaya atau terjadinya suatu perubahan dan perbedaan budaya, dimana di dalamnya dominasi dan resistensi tidak terelakkan, dan Greenblatt seperti memposisikan dirinya "in between" dan berdialektika antara keduanya.

Dari beberapa karya Greenblatt di atas hanya buku yang berkaitan dengan metode dan praktik kritik sastra Greenblatt yang akan diuraikan secara lebih rinci kemudian, yakni buku Renaissance Self-Fashioning: From More to Shakespeare (1980), Shakespearean Negotiations: The Circulation of Social Energy in Renaissance England (1988), dan Marvelous Possessions: The Wonder of the New World (1991).

\section{Renaissance Self-Fashioning}

Dalam buku Renaissance Self- Fashioning, Greenblatt mengikuti Geertz, bahwa karya sastra merupakan artefak kultural. Maka, menurutnya, terdapat fungsi kesusastraan di dalam sistem makna kultural. Bahasa faktanya, sebagaimana sistem tanda, merupakan suatu konstruksi kolektif. Maka, dalam kritik harus menyadari tugas interpretasi, yakni memahami konsekuensi tersebut dengan lebih peka dengan memeriksa kehadiran sosial dari dan di dalam teks sastra.

Kemudian dengan asumsi tersebut, Grenblatt menunjukkan langkah kerja kritik sastranya: 1) pengkajian dilakukan sebagai suatu manifestasi dari tindakan kepengarangan. Aspek pengarang menjadi perhatiannya. Kemudian, 2) tindakan pengarang tersebut dipandang sebagai ekspresi simbolik, suatu kode-kode tekstual berkaitan dengan pembentukan tindakan baik personal pengarang maupun sosiokulturalnya dalam kehidupan masyarakatnya. Pokok pengkajian menekankan bahwa teks dianggap sebagai suatu kode simbolik yang tidak lepas dari suatu konstruksi oleh subjek kekuasaan. Dengan kata lain, sebagai produk atau artefak yang bersifat material sekaligus ideologis sehingga teks dapat berarti memuat pandangan ideologi tertentu yang berkaitan diskursus pada konteks sosiohistorisnya. Dan, 3) interpretasi reflektif dari kode-kode tertentu yang dikonstruksi oleh kekuatan sosialnya. Teks produk pengarang dan pengarang sendiri diprosisikan sebagai bagian dari jaringan diskursus dan bagian masyarakatnya. Praktik tersebut oleh Greenblatt disebut sebagai fungsi interpretasi seperti tiga serangkai dalam sastra yang tidak bisa tidak mesti dikaji seluruhnya.

Mengacu pada langkah kerja atau cara analisis tersebut, mula-mula Greenblat menguraikan konsep diri (self) pengarang. Kondisi diri More diuraikan pada bab I. Menurut Greenblatt, terdapat konflik yang dialami oleh diri pengarang Thomas More dalam menuliskan cerita (fictionalizing). Konflik tersebut dibentuk oleh respon konflik antara yang publik (luar) dan (dalam) pribadinya. Hal itu oleh Greenblatt ditunjukkan di dalam karangan More, Utopia. Dengan demikian fiksionalisasi More sebenarnya telah menceritakan dua sisi dari dirinya: antara posisi sebagai pengarang yang menulis Utopia ia dapat menenangkan dirinya, yang sekaligus telah menyangkal kediriannya sendiri.

Kemudian Greenblatt melanjutkan pada bab II dengan memeriksa bahwa kedirian (selfhood) More terbuka, tidak lepas dari, konflik agama (kekuasaan) yang melibatkannya. Greenblatt mengkaji secara luas dengan 
melibatkan pengaruh sosial dan psikologis pada reformasi Protestan abad ke 15 dan awal abad 16. Kitab Bibel dan agama menjadi kekuatan yang dapat mengendalikan penulisan (percetakan) pada masa tersebut. Greenblatt menyimpulkan bahwa tulisan (More) dapat menghubungkan antara Kata Tuhan dan internalisasi cara hidup orang Kristiani. Meski demikian, tulisan juga berpotensi untuk mengkespresikan perlawanan terhadap kekuasaan institusional. Hal terakhir ini seperti tulisan Tyndale. Bagi Greenblatt, More dan Tyndale diposisikan berseberangan dalam pandangan politik masa Reformasi. Pemetaan posisi pengarang tersebut oleh Greenblatt dimaksudkan untuk memeriksa realisasi kedirian (selfhood) mereka yang dibentuk (fashioned) oleh kekuasaan besar pada masa itu ketika masa peralihan kekuasaan gereja dan Negara.

Pada bab III Greenblatt menguraikan puisi Thomas Wyatt dalam konteks riwayat pengarang Wyatt di bawah rezim Henry. Bagi Greenblatt, puisi-pusi Wyatt mempunyai tujuan ganda: menyebarkan ajaran Zabur (psalm) yang pada akhirnya puisi berfungsi sebagai karya dari keterampilan bersastra, dan di sisi lain ditekan oleh syarat-syarat dari istana sehingga puisi tampak sebagaimana suatu diplomasi. Tujuan ganda puisi Wyatt merupakan sebuah "jarak internal" antara maksud pengarang dan diskursus (Greenbalt, 2010: 153). Tetapi jarak tersebut memungkinkan teks sastra "terlibat dalam refleksi yang kompleks atas sistem nilai yang menggerakkannya" (Greenbalt, 2010: 156).

Dalam kondisi demikian, diantara dua kutub besar yang berbeda, Wyatt tidak tampak melibatkan dirinya dalam suatu penciptaan karya reflektif dalam kompleksitasnya. Hal ini karena kedirian Wyatt kurang stabil, dari sifat eksternal pengarang, sehingga Wyatt kurang memiliki posisi yang aman untuk melakukan refleksi. Sedangkan More dan Tyndale memiliki posisi lebih aman, bersikap secara reflektif atas keraguan-keraguan posisi kediriannya. Bagi mereka kata-kata tidak memiliki jarak internal. Bagi More, fiksionalisasi cenderung seperti penyerapan (absorption) Gereja; sedangkan bagi Tyndale, penyerapan Kata Tuhan.
Menurut Greenblatt, di bawah rezim Elizabeth sebuah pola muncul dari penjelmaan relasi kekuasaan ke dalam relasi erotik, sebagaimana klaim Freud bahwa peradaban berjalan menuju seksualitas dengan cara yang sama. Tokoh Ksatria dalam Faerie Queenenya Edmund Spenser merepresentasikan kompleksitas penyairnya dalam pola subjection (penaklukan, penundukan). Greenblatt memeriksa mengapa Kesatria Temperance bersedia berurusan dengan Bower of Bliss. Hal ini bagi Greenblatt "seperti suatu penduduk atau lapisan dari populasinya yang memperlakukan (menanklukkan) satu sama lain untuk eksploitasi" (Greenblatt, 2010: 173).

Pada bab V diuraikan puisi-puisi Spenser merupakan penuh keterlibatan dengan kekuasaan, sebaliknya dengan drama Marlowe yang subversif. Selain itu, Greenblatt juga menjelaskan bahwa tokoh-tokoh Marlowe tetap membatasi diri sehingga identitas tampak dibuat-buat. Tokoh-tokohnya yang subversif seperti tidak terlibat 'di dalam' keadaan, seperti meloncati suatu masa dimana ia hidup di dalamnya. Greenblatt juga membuat pemetaan posisi Spenser dan Marlowe yang bertentangan, sedangkan Shakespeare di antara keduanya. Pemetaan tersebut kemudian didasarkan pada improvisasi pengarang. Greenblatt kemudian, pada bab VI, menyebut mode self-fashioning yang dapat memanipulasi kemampuan improvisasi (improvisation), dimana ia mengemukakan posisi Shakespeare tersebut seperti pada tokoh Iago (dalam Othello). Improvisasi digambarkan sebagai manipulasi yang oportunis yang tampaknya stabil dan established. Maka, Iago dan juga Othello merupakan produk "doktrin seksualitas Kristen yang sudah berabad-abad lamanya" (Greenblatt, 2010: 246).

Manipulasi Iago dari relasi dimana ia dan Othello berpijak pada doktrin tersebut oleh Greenblatt dilihat sebagai sesuatu yang khas renaissans dari apa yang disebut Lacan di dalam kritiknya terhadap Freud mengenai "ketergantungan dari setiap diri (self) yang paling dalam pada sebuah bahasa" (Greenblatt, 2010: 245). Iago sepenuhnya tergantung pada bahasa 
untuk mendapatkan akses kepada Othello, dan dalam padaitu,ia mesti mereproduksinya di dalam dirinya sendiri. Dengan demikian, kekuasaan improvisasi mampu menginternalisasi dan memanipulasi sesuai dengan ketergantungannya. Improvisasi Iago dalam memanipulasi bahasa juga untuk mewujudkan jarak internal seperti tampak pada posisi Wyatt, yang mewujudkan dan mentransormasikan antithesis di antara More dan Tyndale. Demikian strategi dialektis Greenblatt dalam Renaissance Sel-Fashioning.

Selanjutnya pada bab VI Greenblatt menguraikan self fashioning Iago untuk menunjukkan bahwa self-fashioning Renaissans sebagai sebuah watak mendasar dan sebuah alat cerita yang sangat penting. Greenblatt menggambarkan self-fashioning dari apa yang disebut Geertz dengan 'mekanisme kontrol' yang mengkonstitusi sebuah kebudayaan. Dari improvisasi tokoh Iago Greenblatt menunjukkan kemampuan pengarangnya. $\mathrm{Hal}$ ini untuk memberlakukan mekanisme kontrol mengurungnya ke dalam satu panggung, budaya Renaissans. Demikian buku Renaissans SelfFashioning merupakan realisasi dari kritik sastra Greenblatt.

\section{Strategi Dialektis Greenblatt: Antara Marxisme dan Poststrukturalisme}

Startegi dialektik tersebut kemudian dirumuskan sendiri oleh Greenblatt pada "Towards a Poetics of Culture". Pada tulisan tersebut Greenblatt menguraikan gagasan Marxis Jameson dan poststrukturalis Lyotard (Greenblatt, 1990:146-160) untuk memposisikan kritik sastra Greenblatt yang bergerak di antara keduanya, gerakan bolak-balik seperti ayunan (oscillation); Seluruh proses sirkulasi diidentifikasi sebagai sebuah dialektika totalitas dan diferensiasi, sebagai sebuah kekuatan sosial dimana pergerakannya secara ekstrem di antara yang sama dan yang berbeda.

Dialektika Jameson, menurut Greenblatt, mengarah pada keseluruhan diskursus, dengan mengungkap kesalahan-kesalahan dari suatu ruang artistik yang terpisah-pisahkan; antara teks yang puitik dan sosio-politik menabalkan keterpisahan dari yang privat dan yang publik, yang psikologis dan sosial. Dengan demikian, diferensiasi agen-agen kapitalis merupakan pemisahan yang represif.

Pada sisi lain Lyotard berusaha menarik diri dari integrasi dan mengarahkan pada diferensiasi semua diskursus. Kapitalisme bagi Lyotard tidak menabalkan pembedaan (seperti Jameson) tetapi mempertanyakannya, dan mencoba membuat sebuah bahasa/diskursus tunggal atau jaringan yang tunggal. Maka, kapitalisme menjadi agen totalisasi yang monologis.

Jika Jameson bergerak dari diferensiasi ke totalisasi, sebaliknya dengan Lyotard dari totalisasi ke diferensiasi. Bagi Greenblatt, kapitalisme memiliki efek kontradiktif, maka kontradiksi tersebut dengan sendirinya menunjukkan kekurangan konsepsi kapitalisme Jameson dan Lyotard. Demikian Greenblatt melihat kontradiksi kapitalisme tersebut seperti halnya sejarah seperti hiasan dan ilustrasi yang bersifat anekdot.

Greenblatt melihat bahwa kekuasaan tidak didasarkan pada suatu asumsi dari posisi yang stabil, menjadi totalitas atau diferensiasi, tetapi pada gerakan bolak-balik antara keduanya. Hal tersebut sebagaimana ciri masyarakat kapitalis sejak dari abad ke-16, yakni "membangun ranah diskursif yang berbeda-beda dan meruntuhkan ranah-ranah itu satu sama lain" (Greenblatt, 1990: 153)

Dari analisis tersebut, Greenblatt yang menekankan gerak bolak-balik antara totalisasi dan diferensiasi, keseragaman dan perbedaan, menjadi jelas dialektika Greenblatt, yakni dengan yang membangun puitika perilaku keseharian dalam suatu masyarakat kapitalis yang memiliki konsekuensi penting bagi praktik analisis teks seorang pengarang. Pertama, gagasan suatu teks berangkat dari keterbatasan teks tradisional oleh konsep diskursus dimana, Foucault menunjukkan bahwa pemikiran sebagai praktik sosial. Kedua, suatu teks yang terberi (given) bukan hanya sebuah fragmen dari keseluruhan diskursus, tetapi juga tunduk pada dialektika kultural yang membentuknya, dan seperti tergantung antara dua ketegangan besar. 
Kehatian-hatian Greenblatt dalam praktik analisisnya tersebut berbeda dengan para new historisisme lainya. Jonathan Dollimore, misalnya, yang tampak terang secara politik dan ideologis, cenderung pada materialisme kultural. Dollimore sebagaimana Greenblatt, melihat 'diri' manusia sebagai produk dari momen historis yang partikular, pengalaman manusia dan kesadaran kognisi dikonstitusi oleh struktur sosial dan ideologis secara historis. Tetapi tidak seperti Greenblatt, Dollimore lebih tegas menekankan strategi perlawanan ideologis. Ideologi lebih cenderung tampak (seperti ideologi yang dicurigai) mencoba memberi kesan pada pikiran individu-individu, yang dengan demikian menolak dan meminggirkan pandangan yang tidak sepakat.

Sebagai perlawanan, ideologi dominan dipandang sebagai lawan, sedangkan yang marginal dibela. Jika klaim-kebenaran atas kritik ideologi tersebut berhenti pada penekanan motif ideologis, bagi Greenblatt hal itu tidak cukup. Menurutnya, mesti melanjutkan proses dialektis antara totalisasi dan diferensiasi, sebagaimana relasi antara individu dan teks, antara individu dan diskursus, seperti dalam buku RenaissanceSelfFashioning, atau pada "Invisible Bullets" dalam Shakespearean Negotiations.

Dengan demikian, tuduhan Brannigan kepada Greenblatt dalam hal totalisasi kekuasaan di dalam analisis tekstualnya kurang tepat. Menurut Brannigan (1998: 53), Greenblatt telah mewarisi kekeliruan Foucault yakni dengan memaksakan pandangan yang monologis atas relasi-relasi kekuasaan pada masa lampau sehingga mereduksi sejarah dalam segala kompleksitasnya, suatu perbedaan bentuk sosial dan kultural yang luas dijelaskan sebagai fungsi dari satu mode tunggal kekuasaaan.

\section{Shakespearean Negotiations (1988)}

Dalam Shakespearen Negotiation Greenblatt berusaha mengartikulasikan cara-cara yang beragam dimana makna teks tertulis dikonstitusi, sebagaimana pada basis dimana makna berada. Cara-cara lama dan idiom konvensional tidak mencukupi digunakan untuk menangkap relasi yang rumit antara teks dan konteksnya (seperti alegori, simbolisme, mimesis, dan lainnya) digantikan oleh suatu penyusunan kata (pharseologi) yang tampaknya menjadi metaforis, tetapi pada waktu yang sama melekat suatu usaha yang mendukung untuk menggolongkan (memasukkan) semua bentuk dari produksi sosial, menjadi kesusastraan atau perdagangan, di bawah suatu idiom deskripsi yang umum.

Penggunaan metafor ekonomi Greenblatt merupakan bukan suatu usaha untuk menghidupkan kembali (enliven) bahasa kritik, seperti "pembungkusan, seolah-olah itu untuk dijual", nilai dan makna diperoleh dari pasar di mana diskursus (metafor) beroperasi. Metafor, terutama gagasan pasar bebas, juga merupakan konsekuansi langsung dari pengertian kapitalisme Greenblatt.

Disebutkan di awal pada pembandingan antara Jameson dan Lyotard, Greenblatt tidak menolak kapitalisme baik totalisasi atau diferensiasi. Justru gerak bolak- balik (oscillation) antara totalisasi dan diferensiasi dipandang sebagai sebuah kekuatan yang menghasilkan (produktif). Dalam atmosfer negosiasi dan pertukaran (exchange), sirkulasi arus yang berbeda-beda, batas-batas antara individu, bangsa, perbedaan kelas, dan kontak sosial, (akan) mudah diseberangi dan dengan demikian dipertanyakan.

Sebagaimana dalam perdagangan dan perusahaan niaga membutuhkan gagasan untuk mobilisasi dan demikian juga membutuhkan produksi individualitas. Bagi Greenblatt, gagasan perdagangan komersial tersebut meliputi tidak hanya ekonomi tetapi juga ranah sosial dan artistik. Relasi seni dan masyarakat digolongkan ke dalam proses negosiasi dan pertukaran seperti dalam ranah ekonomi.

Negosiasi dan pertukaran tersebut tampak pada Richard II-nya Shakespeare, yang mengatasi batas-batas konvensional teater menjadi "open streets and houses" sehingga menerima maknamakna baru dan membentuk (fashions) identitasidentitas baru, seperti ketidakpuasan Ratu Elizabeth. Pertunjukan tersebut menurut Greenblatt merupakan displacement dan bukan 
sebuah penyimpangan, bukan pembajakan versi legal produksi artistik. Produksi tekstual bukan merupakan ruang milik pribadi; pengarang tidak sepenuhnya memiliki diri memperhatikan bagaimana sastra dan lintasan historisnya, teks sastra ditempatkan dalam ruang sejarah. "Aku bermimpi berbicara dengan orang mati, dan bahkan sampai sekarang aku tidak bisa membuang mimpi itu. Tetapi yang jadi persoalannya adalah aku hanya mendengar satu suara, suara 'the other'. Jika hanya mendengar satu suara, aku tidak bisa tidak mendengar suara-suara lain. Dan jika ingin mendengar suara 'the other', aku mesti mendengar suaraku sendiri. Cara bicara orang yang mati itu seperti cara bicaraku sendiri..." (Greenblatt,1988: 20).

Dalam Shakespeare Negotiations, Greenblatt mengemukakan mengenai dasar material dari prinsip makna dan nilai, dengan mengidentifikasi peredaran yang menyebar di dalam pola negosiasi dan pertukaran sebagaimana energi sosial. Menurutnya, kegembiraan, kesedihan, kegelisahan, kelegaan, dan bentuk emosi lainnya merupakan suatu teks atau pertunjukan yang mungkin menginspirasi audiens atau pembaca, sebagai sebuah hasil dari "energi sosial" dituliskan di dalam karya tersebut. Kehidupan dari karya sastra tersebut terwujud (materialize) di pentas, cerita, pakaian, bahasa, metafor, simbol, upacara yang ingin membuat (make up) suatu pertunjukan.

Dengan demikian, puitika kultural berupaya menjelaskan mengapa dan bagaimana baik intensitas pengalaman maupun produkproduk kultural lainnya dibutuhkan. Sedangkan energi sosial sebagai dasar atau mendorong aktivitas primer manusia yang, oleh Greenblatt yakini, bukan bersifat material tapi bersifat simbolik. Sehingga, dengan kata kepengarangan, akhirnya seperti sesulit dipahaminya diri pembaca), mereka akan menjadi ada sebagai fenomena di dalam publik pasar.

Dalam tulisan "The Circulation of Social Energy" Greenblatt mengakui bahwa ia lain, teks merupakan bagian dari produksi simbolik tersebut, dan begitu juga semua artefak sosial, termasuk sejarah. Sedangkan energi sosial dapat beredar secara bebas dalam tatanan simbolik tersebut, dan pada waktu yang sama mengkonstitusi dasar bagi eksistensi tatanan simbolik. Energi sosial berfungsi tidak hanya seperti sebuah mata uang, tapi juga seperti sesuatu "di bawah mata uang" (undercurrency). Semua itu adalah lapisan bawah (substratum) dari alam simbolik dan bukan suatu bentuk dari produksi sosial.

Teks dikatakan bermakna karena pembaca menginvestasikan emosinya di dalam artefak kultural, sehingga energi sosial tersebut kembali kepada pembaca ketika pembaca mengkonsumsi produk-produk sosial tersebut, dan ketika pembaca menafsirkan teks-teks tersebut. Pandangan dasar Greenblatt adalah setiap sesuatu yang diproduksi oleh masyarakat memenuhi syarat sebagai energi sosial, semisal "kekuasaan, karisma, kegembiraan seksual, pembayangan kolektif, ketakjuban, hasrat, kegelisahan, perasaan religius, intensitas yang mengapung-bebas dari pengalaman," yang semua itu merupakan fenomena psiko-fisikal (Greenblatt, 1988: 1)

\section{Renaissans dan Shakespeare}

Dalam Shakespearean Negotiations, Greenblatt diantaranya menulis-Fiction and Friction" dan-Shakespeare and Exorcist'. Kedua tulisan tersebut Greenblatt mempersoalkan individu dan kelompok yang dimarjinalkan dan fenomena pada masyarakat, dan dalam penafsiran teks-teks ia tidak berangkat dari alur utama, tetapi dari "pinggiran", yang subalur. Berangkat dari suatu segi yang tampaknya insignifikan dari teks, Greenblatt bergeser untuk menemukan segi minor dalam suatu konteks kultural yang lebih luas, dimana dari semua itu untuk mendapatkan kemungkinan makna yang besar, yang mungkin memberikan suatu cahaya baru yang menyeluruh pada teks yang ia atur untuk menafsirkan.

Dalam "Fiction and Friction" Greenblatt menguraikan formasi identitas Renaissans, khususnya pada tema pakaian- perkawinan dan identitas seksual yang keliru dalam relasinya dengan teks drama Elizabeth 
(Greenblatt,1988:66-93). Ia juga dengan mensejajarkan sebuah cerita yang cukup fantastis dari buku- buku pelajaran pada awal abad ke17: Des Hermaphrodits, accouchemens des femmes, et traitement qui est requis pour les releuer en sante', et bien eleuer leurs enfans-nya Jacques Duval (Rouen, 1603) dengan Twelfth Night-nya Shakespeare. Teks Duval tersebut bagi Greenblatt tidak menunjukkan "batas-batas individualism yang berdasarkan norma", tetapi memberikan suatu gagasan "diskursus di luar dari subjek spesifik yang secara historis dibentuk (fashioned)" dan "disatukan secara komunal" (Greenblatt, 1988: 75).

Dengan demikian pada setiap orang diskursus menanamkan suatu-beban yang di luar pusat pendefinsian (off-center), semisal, suatu pencampuran-atas aturan-aturan seksual, yang memainkan suatu aturan kritis dalam pembentukan identitas. Persoalan perkawinan (Jeane dan Marin) kemudian menjadi tanda suatu pergerakan dari individualitas partikular ke arah norma komunal dan wilayah pembicaraan publik, sebab Renaissans "cenderung membentuk pengertian nomatifnya dengan perencanaan yang luar biasa" (Greenblatt, 1988: 77).

Meski demikian, Greenblatt melihat bahwa karakteristik masyarakat Renaissans khususnya aturan seksual ternyata tidak stabil sebagaimana anggapan pada umumnya. Perlawanan terhadap aturan-aturan tersebut juga merupakan negasi dialektis yang melalui suatu pentotalisasian masyarakat dapat terbangun dengan sendirinya. Kebingungan gender tersebut, himpitan di luar pusat pendefinsian (off-center) 'tersebut, dapat juga dilihat bekerja dalam "cerita bayangan skandal" yang secara terus-menerus membayangi Twelfth Night-nya Shakespeare. Meski komedi ini pada esensinya merupakan sebuah permainan yang amat sangat membingungkan menyembunyikan dan keruwetan cinta-kasih yang secara rapi, tapi pada akhirnya terpecahkan dan tampak sebagai "sebuah pertunjukan hasrat homoerotis."

Greenblatt menjelaskan dari plot utama, yang menunjukkan adanya hubungan antara pangeran yang sempurna, Sebastian, dan putri Olivia yang bijak dan kaya. Tetapi, plot bayangannya perihal pakaian-perkawinan dan gaun-pasangan pengantin Greenblatt melihat adanya persoalan kekuasaan yang kemudian membangun kembali (re-establish) pola penentraman sosial dan aturan seksual pada akhirnya. Selain itu, Greenblatt juga menemukan nada-tambahan erotis dalam persahabatan yang akrab antara Antonio dan Sebastian (saudara kembar Viola). Seksualitas dalam Twelfth Night terletak pada penyimpangan-dari objek yang diinginkan ke arah sebuah objek yang marginal, suatu tubuh seseorang yang diketahui. Penyimpangan yang dimaksud Greenblatt tersebut dipahami pada suatu perlintasan atau aturan sosiokultural, bahwa sifat dasar (alami seksual) merupakan suatu tindakan yang tidak sehat pikiran (unbalancing act) (Greenblatt, 1988: 68).

Dalam Shakespearean Negotiations Greenblatt juga memeriksa Saturnalia, sebuah perayaan bulan Desember masa Romawi. Menurutnya, dalam strategi perlawanan terhadap aturan sosial dan seksual tidak perlu mengancam tatanan yang berlaku, dengan kata lain, ketika yang normal itu terjamin, maka yang perlawanan mestinya bersifat lunak atau halus. Etika kasih-sayang homoerotic yang bertubi-tubi (terus-menerus) mengaburkan gender yang tetap bersikeras menentang justru seperti playful aberration, penyimpangan yang dimain-mainkan sehingga tampak lucu. Di sini Greenblatt tampak menggunakan anekdot yang berangkat dari metafor, kemudian menariknya dalam ruang diskursus. Seperti halnya Foucault, Greenblatt menguraikan kekuasaan (energi sosial) beserta subversi dan dominasi, dari tubuh yang faktis dan privat ke material- diskursus, dengan menggunakan istilah-istilah ekonomi.

Dari Shakespeare kemudian Greenblatt dalam analisis diskursus dihubungkan dengan Duval, Greenblatt mencoba menunjukkan mengapa dan bagaimana pengkaburan gender di dalam Twelfth Night dan Des Hermaphrodits menyumbangkan pembentukan (fashioning) identitas. Dalam teks Duval, Greenblatt menemukan suatu catatan ganda keaslian gender: keadaan laki-laki yang spiritual, intelektual, dan kuat, sedang perempuan yang ditandai dengan 
dingin, pasif, dan lemah. Tetapi, keduanya, baik lelaki maupun perempuan sama-sama diperlukan dalam memperoleh air mani sebagai akses nafsu, yakni melalui kesuburan perempuan dan kelelakian.

Mengacu pada teori tersebut (teori dalam karya Galen), perbedaan seksual dibangun dengan suatu perjuangan antara elemen laki-laki dan perempuan di dalam tubuh. Manusia, dalam kasus ini, memiliki suatu alam ganda yang dengan segera menjadi satu. Sedangkan, mengacu pada teori yang lain, kelamin perempuan adalah kebalikan dari kelamin laki-laki, dan untuk mencapai identitas seksualnya mesti melalui perempuan, melalui panggung perempuan. Lelaki akan tampak sempurna dengan adanya tonjolan dari tubuhnya, dengan terpaksa melalui tubuh perempuan yang kurang sempurna. Psikologi perempuan tampak lebih pendek daripada tonjolan tubuh laki-laki. Maka, teori ini membayangkan adanya kesatuan struktur genetis yang dapat dibagi dalam dua bentuk, internal dan eksternal: sebuah alam tunggal yang menjadi ganda.

Dalam teori klasik, relasi genetis mencoba menjaga tercipta suatu keserasian yang harmonis antara seks dan gender. Dengan menggunakan perbedaan teori-teori tersebut, menurut Greenblatt, akan menjadi jelas dualitas dan kontradiksi di dalamnya. Maka, determinasi gender dan identitas menurutnya, didasarkan pada legitimasi sekaligus subversi terhadap aturan seksual. Sementara gagasan "pembelokan" Greenblatt diperlukan sebagai kebutuhan untuk mengatasi struktur, yakni dengan suatu gerakan bolak-balik seperti bandul ayunan (oscillation), antara totalisasi dan diferensiasi, sebagaimana dialektika dalam self-fashioning. Oleh karena itu, trans-fethisme dalam Twelfth Night "merepresentasikan sebuah identitas antara lelaki dan perempuan," tanpa merepresentasikan identitas tersebut sebagai realitas. (Greenblatt,1988: 82).

Selain itu, menurut Greenblatt dualitas dan kontradiksi dalam Twelfth Night juga menunjukkan kekacauan seksual. Baginya, kekacauan (confusion) merupakan bagian dari diskursus, sebagaimana panggung (teater) yang bersama-sama dengan teks seperti dalam teksteks Duval. Kemudian, representasi kekuasaan erotik tersebut dikembalikan kepada audiens atau pembaca 'dengan kepentingan' sebagai bagaian dari proses negosiasi dan pertukaran.

"Renaissanse" yang Greenblatt bicarakan adalah Renaissans dalam bingkai diskursus, dengan menekankan pada yang plural (prodigious) - secara tidak langsung sebagai implikasi dari "signifikansi dari marginalitas". Atas dasar tersebut new historisisme mengklaim berbicara atas nama yang dimarginalisasi, yang diopresi, dan atas nama yang dipandang terbelakang oleh suatu masyarakat. Persoalan seksual dan tatanan sosial Renaissans dalam Twelfth Night diruntuhkan hanya dengan gaunpengantin yang ditafsirkan sebagai suatu gerakan penyimpangan (sekaligus perlawanan) hermeunetika dalam pandangan puitika kultural Greenblatt.

\section{Negosiasi dan Pertukaran}

Konsep negosiasi dan pertukaran dieksplorasi Greenblatt dalam tulisan "Shakespeare and the Exorcists" (Greenblatt, 1988: 94-128). Greenblatt mencoba mengungkap relasi yang lebih kompleks dengan menyisakan pola negosiasi dan pertukaran yang berangkat dari sudut pandang yang dimarginalkan di dalam masyarakat: konsep kerasukan atau kesurupan dimaknai menjadi perampasan (dipengaruhi, dirasuki, dimiliki-the possessed).

Sebagai pembaca, Greenblatt memperhatikan kedekatan relasi antara King Lear dan buku, yang oleh Samuel Harnett disebut, $A$ Declaration of Egregious Popish Impostures (1603), sebuah deklarasi ajaran katolik yang terkenal. Buku Harsnett tersebut merekam sebuah ajaran yang menakjubkan tentang pengusiran setan yang dilakukan oleh sebuah golongan Jesuit pada 1585-1586. Tetapi, justru ajaran tersebut menjadi bumerang bagi katolik, buku tersebut mencela praktik-praktik Jesuit sebagai suatu kecurangan, memindahkan 'sifat' jahat (demonic) yang tidak di dalam diri yang dirasuki, tetapi di dalam pengusiran 'diri' mereka.

Buku karya tersebut terbukti berada di 
dalam masyarakat yang hendak meredefinisi nilainilai utamanya, terutama definisi yang sakralyang pada masa itu dilegitimasi oleh otoritas. Selama berabad-abad karisma pengusiran setan tersebut menjadi epitome (lambang) dan epiphany yang sakral dalam agama Kristen Latin. Secara alamiah Aliran Protestan mencoba - mengakhiri untuk kebesaran karisma tersebut". Pengusiran setan baik yang dilakukan oleh gereja (Anglikan) maupun pengadilan merupakan suatu tuduhan (penipuan) yang dirancang untuk mengusir 'diri' manusia -yang dianggap bid'ah, tidak patuh, dan menyimpang dari doktrin (otoritas) gereja yang sakral sehingga setan telah menaklukkan mereka, sehingga menjadi suatu "kebijaksanaan" menggantung manusia yang dirasukinya (Greenblatt,1988:97).

Menurut Greenblatt, realisasi pengusiran setan tersebut merupakan suatu praktik Perjanjian Baru yang tidak mengingkari pengaruh setan, tetapi menyarankan bahwa hal tersebut memproduksi suatu ilusi akan adanya kerasukan roh jahat (demonic possession). Maka, karisma seorang pengusir setan semata-mata tergantung pada kesan yang dibuat atas pikiran-pikiran penonton, dan hal itulah yang direalisasikan agar kesan tersebut dikuatkan dan dimanipulasi oleh pertunjukan yang dituliskan, atau dengan kata lain, roh jahat yang di-(panggung)-pertunjukan.

Pada lain hal, kecenderungan agresif Protestan yang menyerang gereja katolik pada teater kadangkala juga disebabkan oleh pakaian pendeta Katolik dijual kepada aktor atau pihak teater, pihak yang rela membayar lebih kostum bagus adalah demi pertunjukan yang bagus. Maka, sejak saat itu pakaian bukan sekedar 'pakaian' tapi juga merupakan kekuasaan simbolik yang dibutuhkan. Greenblatt menekankan bahwa masa Elizabeth ditandai oleh suatu 'obsesi' fetishistik terhadap pakaian sebagaimana sebuah tanda (nilai) dari status dan derajat (Greenblatt, 1988: 113).

Dengan cara demikian, Harsnett telah menjual 'ritual' pengusiran setan kepada teater (dan Shakespeare) yakni dengan membaca Declaration, menerima tawaran, menuliskan dan mementaskannya; juga tidak hanya ajaran pengusiran setan, tetapi juga terhadap Harsnett pada 'ajaran' pengusiran setan. Untuk mendukung klaim tersebut, dalam teks Shakespeare, Greenblatt mengacu pada adegan dalam King Lear dimana Edgar, berpura-pura menjadi orang gila Poor Tom, dan ingin membunuh ayahnya yang buta, Pangeran Gloucester, dengan menipunya dan agar seolah-olah ayahnya bunuh diri. Seperti kerasukan, yang berpura-pura gila, Edgar membuat ayahnya yakin bahwa mereka berdiri di atas tanah yang rata-kenyataannya, di tepi jurang yang curam, hal yang menegaskan bahwa orang lemah/miskin terlalu lemah/ sulit memahami keadaan di sekitarnya, ketika Gloucester melangkah ke depan, ia benar-benar terjatuh ke jurang. Edgar, seketika merubah aturan (sikap awalnya yang berpura-pura gila), ia kemudian mengandaikan dirinya seperti 'melihat setan yang keluar dari tubuh orang tua'.

Dari pembacaan tersebut pada satu sisi bukan pada penggambaran pengusiran setan, karena, pertama, memang bukan pengusir setan, dan kedua, karena setan yang memisah-diri dari Gloucester tidak benar-benar di dalam (inside) manusia tetapi agaknya setan dalam penyamaran Poor Tom; Pada sisi lain, Shakespeare tidak membuat alasan gambling 'apa maksud Edgar meyakinkan ayahnya' atau apa yang diinginkan Edgar sebenarnya. Greenblatt berpendapat bahwa pengusiran setan berkaitan dengan kecurangan (penipuan) atau kepura-puraan. Meski ia tidak menganggap dirinya menjadi seorang pengusir setan, Edgar mencoba untuk 'mengusir setan' keputus-asaan ayahnya dengan demonizing (keadaan yang menyedihkan dari pikirannya dianggap sebagai setannya).

Dengan demikian, apa yang dimaksud Harsnett dapat berarti sebaliknya, yakni pihak pengusir setan sebenarnya (juga) mengalami penderitaan secara psikologis, merasa bersalah, kegusaran, dan frustasi terhadap keadaan dengan mengalihkannya pada alibi pengusiran setan untuk merealisasikan kegelisahannya. Oleh karena itu, Harsnett berarti ingin membersihkan dunia dengan ajaran pengusiran setan, dengan logika dominasi-subversi: Jika pengusir setan adalah penipu, maka harapan penebusan 
dosa dihancurkan. Sebaliknya, Shakespeare merealisasikan kebutuhan pengusiran setan dan mengintensifkan kebutuhan tersebut sebagai suatu pengalaman teatrikal (Greenblatt, 1988: 126).

Cerita Gloucester dan putranya adalah cerminan dari plot utama Lear dan anak perempuannya. Persamaannya, Gloucester dan Lear diarahkan pada keputusasaan (hilang harapan). Gloucester memiliki pengusir setan (Edgar), sedangkan Lear tidak. "Ketiadaan dari harapan menebus dosa" (Greenblatt, 1988: 124) tersebut disajikan dalam pertunjukan yang murung, sekaligus memberikan kesaksian bahwa kekuasaan religius memproduksi sebuah sandiwara. Meski Shakespeare tidak menegosiasikan baik pengusiran setan dalam ajaran katolik atau protestan, tapi ia mengakui perlu mengangkatnya dalam teks atau panggung, dan alasan dari pengakuannya adalah kesadaran untuk suatu penebusan bagi Shakespeare.

Pola negosiasi dan pertukaran oleh Greenblatt dipandang sejajar dengan pola kerasukan, pengusiran setan, dan penebusan dosa. Dan pada kenyataannya, menurut Greenblatt, meski tidak dipercayai lagi ritual pengusiran setan, meski hal itu dianggap sebagai penipuan, pola seperti dalam King Lear tersebut pada dasarnya tetap berlaku dan bahkan lebih intensif, karena pola dan ritual (tata cara, formasi, norma, nilai) tersebut telah tertanam sejak berabad-abad dengan kekuasaan dan pembatasan (Greenblatt, 1988: 128).

Akhirnya, dari King Lear dan Twelfth Night, Greenblatt mengartikulasikan makna dan membuktikan bahwa karya sastra tidak lagi dipahami sebagai pusat yang otonom dan terpisah tetapi sebagai suatu perhubungan dengan konteks sosio-historisnya, baik relasi secara simbolik dalam bingkai biografis maupun konteks pada masa teks tersebut diproduksi dan masa pembaca.

\section{Marvelous Possessions (1991)}

Dalam buku Marvelous Possessions Greenblatt menguraikan teks naratif travel writing, baik narasi fiksional maupun historis.
Greenblatt mencoba menunjukkan operasi kerja dialektik antara diferensiasi dan asimilasi (totalisasi) pada budaya penjelajah dan budaya asing. Dalam buku ini ia menguraikan narasi Sir John Mandeville (penjelajah abad ke-14 secara imajiner) dan Columbus. Menurut Greenblatt, keduanya merepresentasikan narasi eksotik, dan terutama teks-teks Columbus memperlihatkan adanya shock atau gap pada mula bertemu dengan alterititas.

Greenblatt memaparkan ketakjuban (marvelous) dan keheranan (wonder) para penjelajah. Hal itu dijelaskan sebagai pokok penanda strategis dalam representasi Barat, yang sekaligus juga merupakan sebuah langkah awal untuk 'membungkus' yang lain (the other) ke dalam jaringan diskursus Barat. Dalam tulisan yang terkenal "From the Dome of the Rock to the Rim of the World", Greenblatt mencoba menunjukkan bagaimana Travel-nya Mandeville ditandai oleh sebuah ketegangan intern yang dapat mendistorsi realitas antara suatu dunia yang familiar (yang- dikenal) dengan dunia yang-tidak-dikenal (baru), antara dunia yang diandaikan pertama dengan perbedaan dunia yang mengherankan dan eksotis.

Pada bagian lain dari buku ini, Greenblatt menguraikan dengan sebuah perjalanan melalui tanah suci (Holy Land) yang akrab dengan narasi Al-Kitab dan pandangan dunia kaum Kristen, tanah suci merupakan tempat akan metonimi kudus. Metonimi, relasi faktual antara penanda dan petanda (suatu tempat suci yang menunjukkan suatu peristiwa dari sejarah suci diasosiasikan dengan tempat tersebut) melebur ke dalam metafor ketika Mandeville mengembara ke yang-tidak-diketahui dan segala sesuatu terlalu seringkali curiga dunia imajiner dan yang bersimpangan (berbeda, lain).

Pandangan dunia kristiani setidaknya merupakan referen yang cukup penting dari teks, tetapi relasi antara penanda dan petanda tidak lagi faktual sebab dengan penggunaan representasi atau metafor: Kota pemujaan di Tibet meniru sebagaimana kebalikan dari civitas Kristiani; Sebuah pemakaman kanibal di mana jenazah tidak 'dimakan' oleh api atau tanah, 
tapi oleh orang yang berkabung (orang yang ditinggalkan), yang tampak sebagai suatu parodi metaforis yang aneh dari kaum Ekaristi (Eucharist). Dalam pemaparannya Greenblatt memeriksa pandangan dunia yang stabil (totalisasi).

Dalam pembahasan mengenai perjalanan Columbus ke dunia baru, Greenblatt mencoba menunjukkan ketegangan dialektis yang sama antara dua motif dominan penjelajah (penjajah): haus emas dan kekuasaan atas nama religius atau semangat misionari. Greenblatt menguraikan mengapa politik imperialis di awal penjelajahan sebagai sesuatu yang tidak pernah terjadi dan apa dasar pemikiran (rasionalitas) di belakang percampuran motif (gold-power dengan misi agama), kemudian mengkaitkan kepada Kristian Columbus jaman sekarang, dengan mode yang bertentangan (dialektik). Greenblatt menemukan bahwa di dalam paradoks Kristiani 'diri yang baru' tidak akan bisa 'sampai ke kehidupan' kecuali membunuh 'diri yang lama', atau dengan kata lain seperti dalam soneta kudus-nya Donne yang dikutip Greenblatt, "Take mee to you, imprison me, for I / Except you enthrall mee, never shall be free" (Greenblatt,1988:70).

Dengan demikian, dalam hal ini untuk lahir kembali orang-orang Indian mesti sebelumnya menjadi budak dulu. Greenblatt berpendapat bahwa aksi Columbus sama dengan pola ini, diinformasikan secara kultural oleh dialektika. Sebaliknya pada perampasan Mandeville terhadap dunia baru (suatu sifat yang mungkinmudah bagi penjelajah yang berkuasa) dalam diskursus Columbus membuktikan shock dan keheranan adalah awal dari adanya alteritas, yang digantikan oleh yang material dengan anggapan bahwa untuk membayangkan integrasi yang lebih menyeluruh ke dalam totalitas diskursus Barat, perlu diciptakan yang lain (the other).

Dalam kasus Mandeville ini, Greenblatt memandang bahwa buku sebagai sesuatu yang "mengurangi hak milik" atau "perampasan yang luar biasa", yang artinya realitas pada buku bukan hanya 'milik' sastra. Hal ini mengacu pada realitas tekstual Mandeville yang fiksional ataupun pengarang Travel yang sesungguhnya tidak-dikenal (tidak diketahui). Mandeville di sini oleh Greenblatt dipandang dalam bingkai sejarah, sebagai sosok masa lampau, yang tidak mungkin dihidupkan kembali. Greenblatt tampaknya ingin menunjukkan konsistensinya pada pandangan 'berbicara pada orang mati' dalam Renaissans Self-Fashioning.

Penguraian pada analisis Greenblatt menunjukkan bahwa suatu teks diinformasikan konteks sosiokultural secara dialektis, sebuah teks merefleksikan sama baiknya dengan referennya, dan menempatkannya secara berbeda, dan sebaliknya suatu konteks sosio-kultur mengkondisikan representasi tekstualnya, dan demikian juga suatu teks yang menginformasikan dan kadangkala sejajar dengan kondisi proses historis. Proses ini seperti yang disebut Montrose di atas, tekstualitas historis dan historistas tekstual.

Selanjutnya Greenblatt mencoba menunjukkan bahwa strategi-strategi kekuasaan yang diproduksi masa penaklukan (Age of Conquest) juga menghasilkan teks-teks yang berkaitan dengannya, dengan kolonialisme dan imperialisme serta apa-apa yang mengikutinya. Greenblatt berusaha menguraikan bahwa teksteks tersebut secara ketat berjejalin dengan konteks sosiokulturnya. Sampai di sini, Greenblatt mengikuti tekstualitas Geertz, bahwa teks sastra adalah bentuk lain dari artefak kultural.

\section{Kesimpulan}

Dari uraian di atas dapat dirumuskan kritik sastra puitika kultural Stephen Greenblatt. Pandangan Greenblatt sebagai pelopor new historisisme bermula dari penolakannya atas pandangan New Kritisisme dalam memperlakukan teks sastra secara otonom. Dengan mengacu terutama pada pemikiran Geertz dan Foucault, Greenblatt menyebut kritik sastra yang dipraktikkannya dengan puitika kultural (cultural poetic). Greenblatt menyatakan bahwa karya sastra adalah produk budaya sebagaimana artefak kultural, yang juga sejajar dengan konsepsi tekstulitas Geertz (budaya sebagai teks). Dengan demikian, teks sastra dan konteks dipandang sebagai suatu jaringan yang berjalinan satu dengan yang lain, demikian 
halnya dengan teks sastra, teks sejarah, teks resmi bahkan personal atau berbagai bentuk teks lainnya, ditempatkan pada rangkaian yang disebut diskursus (Foucault).

Pandangan tersebut berimplikasi pada praktik interpretasi dan analisis dalam kritik sastra. Dalam hal ini Greenblatt menyampaikan tiga langkah kerja atau tiga serangkai: (1) Teks sastra dengan asumsi sebagai suatu manifestasi dari ekspresi kepengarangan baik psikologis, biografis, maupun ideologis. Maka, aspek pengarang menjadi titik perhatian dalam interpretasi dan analisis karya sastra. Kemudian, (2) karya sastra dipandang secara simbolik-struktural sebagai suatu kode-kode tekstual yang pembentukannya erat berkaitan dengan baik ekspresi kepengarangan maupun sosiokulturalnya. Oleh karena itu, pokok interpretasi dan analisis menekankan pada teks, yang diasumsikan memiliki jaringan makna yang tidak lepas dari suatu konstruksi pemaknaan. Dengan kata lain, sebagai produk atau artefak yang bersifat material sekaligus ideologis, teks memuat suatu pandangan pengarang yang berkaitan dengan ideologi tertentu dalam ruang diskursus pada konteks sosiohistorisnya. Selanjutnya, 3) secara reflektif dilakukan interpretasi dan analisis atas kode-kode teks sastra yang dikonstruksi oleh kekuatan sosial di dalam diskursus. Ringkasnya, teks sastra secara historis adalah karya pengarang dan pengarang sendiri diposisikan sebagai bagian dari jaringan diskursus dan tatanan (episteme) masyarakatnya. Maka, yang fokus pengkajian adalah diskursus yang melingkupi dan membentuk penciptaan dan pemaknaan teks sastra. Ketiga praktik Greenblatt ini disebut sebagai interpretasi tiga serangkai puitika kultural yang tidak bisa tidak mesti dikaji seluruhnya.

Kemudian Greenblatt juga mengembangkan analisis tersebut dengan strategi dialektika kultural. Yakni dalam analisis teks sastra mempertimbangkan konsep dominasi dan subversi dengan bergerak bolak- balik diantara keduanya, sehingga dalam menemukan makna akan mengungkap mengapa dan bagaimana diskursus yang membingkai makna dari teks sastra tersebut. dengan demikian, posisi kritik sastra Greenblatt bergerak diantara totalisasi (marxisme) dan diferensiasi (postmodernisme).

Lebih lanjut, Greenblatt juga memberlakukan teorirepresentasidalam relasinya dengan sosiohistoris. Representasi Greenblatt dipandang dalam relasi antara mimetik (tiruan) dan kapitalisme. Menurutnya, representasi adalah kumpulan citra (image) yangdengan tujuan tertentu diakumulasi dan diciptakan serta ditransformasikan secara kultural baik dalam teks sastra maupun dalam bentuk yang lain. Maka, representasi dalam pandangan ini berkembang biak dan beredar (sirkulasi) dalam jaringan diskursus pada waktu dan masyarakat tertentu. Sedangkan konsep-konsep Greenblatt lainnya, seperti self-fashioning, anekdot, negosiasi dan pertukaran hanya memungkinkan dalam interpretasi dan analisis jika metode puitika kultural di atas digunakan.

\section{Daftar Pustaka}

Brannigan, John. 1998. New Historicism and Cultural Materialism. London: Macmillan Press Ltd.

Colebrook, Claire. 1998. New Literary Histories: New Historicism and Contemporary Criticism. Manchester: Manchester University Press.

Coldiron, A. E. B. 2001. "Toward a Comparative New Historicism: Land Tenures and Some Fifteenth-Century Poems". Comparative Literature 53, tahun ke 2, edisi Spring 2001.

Greenblatt, Stephen. 1980. Renaissance SelfFashioning: From More to Shakespeare. Chicago \& London: The University of Chicago Press.

1988. Shakespearean Negotiations: The Circulation of Social Energy in Renaissance England. Berkeley \& Los Angeles: University of California Press. . 1990. Learning to Curse: Essays in Early Modern Culture, New York and London. . 1997. "The Touch of The Real", Jurnal Representation, edisi 57 spesial "The Fate of 'Culture': Geertz and Beyond'. 
et al. 2010. The Cultural Mobillity:

A Manifesto. New York: Cambridge

University Press.

\& Gallager, Catherine. 2000. Practicing

New Historicism. London \& Chicago:

The University of Chicago Press.

Liu, Alan. 1989. "The Power of Formalism: The New

Historicism," dalam English Literary History edisi 56.

Marcus, Jane. 1989. "The Asylum of Antaeus:

Women, War, andMadness "Is there a Feminist Fetishism?" dalam The New Historicism, H.

Aram Veeser (ed.) New York \& London: Routledge.

Newton, Judith Lowder. 1989. "History as Usual? Feminism and the New Historicism" dalam The New Historicism, H. Aram Veeser (ed.) New York \& London: Routledge.

Pease, Donald. 1991. "Toward a Sociology of Knowledge," dalam Consequence of Theory. Jonathan Arac and Barbara Johnson (Ed.). Baltimore: Johns Hopkins UP.

Veensra, Jan R. 1995. “The New Historicism of Stephen Greenblatt: on Poetics of Culture and the Interpretation of Shakespear," dalam History and Theory edisi 34, tahun ke-3. 